\title{
PENGARUH BUDAYA ORGANISASI DAN SUPERVISI AKADEMIK TERHADAP KINERJA GURU SD DI KECAMATAN PINGGIR KABUPATEN BENGKALIS
}

\author{
Valentine Pratiwi 1) \\ Makhdalena ${ }^{2)}$ \\ Nurpit Junus ${ }^{3)}$ \\ 1) Post Graduate Student of Riau University \\ ${ }^{2)}$ Lecturer of Education Management Study Programme PPs University of Riau \\ ${ }^{3)}$ Lecturer of Education Management Study Programme PPS University of Riau
}

\begin{abstract}
This research was aimed at analyzing the influence of organizational culture and academic supervision towards the teachers' work performance at Primary Schools in Pinggir Sub-district, the District of Bengkalis. The data were obtained from government employed teachers of 140 teachers in total being selected using Proportional Random Sampling technique. The collected data were analyzed using double-linear regression. The results of the data analysis provided the evidence that there was a significant correlation between organizational culture and academic supervision towards the teachers' work performance of $12.5 \%$. The findings of the research also proved that organizational culture influenced the teachers' work performance of 9,7\% and the academic supervision influenced the teachers' work performance of 1,9\%. Therefore, it is concluded that organizational culture and academic supervision variables gave a significant correlation towards the teachers' work performance.
\end{abstract}

Keywords: Teachers Work Performance, Academic Supervision, Organizational Culture

\begin{abstract}
ABSTRAK
Penelitian ini bertujuan untuk menganalisis pengaruh budaya organisasi dan supervisi akademik terhadap kinerja guru SD di kecamatan Pinggir kabupaten Bengkalis secara simultan dan parsial. Sumber data penelitian ini adalah guru Pegawai Negeri Sipil sebanyak 140 orang yang dipilih menggunakan Proporsional Random Sampling. Analisis data menggunakan regresi linier berganda. Hasil dari penelitian ini adalah terdapat pengaruh signifikan budaya organisasi dan supervisi akademik terhadap kinerja guru sebesar $12.5 \%$. Budaya organisasi berpengaruh terhadap kinerja sebesar $9.7 \%$ dan supervisi akademik berpengaruh sebesar $1.9 \%$. Kesimpulan dari penelitian ini adalah variabel budaya organisasi dan supervisi akademik berpengaruh signifikan terhadap kinerja guru.
\end{abstract}

Kata Kunci: Kinerja Guru; Supervisi Akademik; Budaya Organisasi 


\section{PENDAHULUAN}

Pendidikan merupakan kunci untuk menciptakan generasi yang unggul dan mampu bersaing. Sejalan dengan UU No 20 Th 2003 Pasal 3 tentang Sistem Pendidikan Nasional maka pendidikan dinilai sebagai faktor penting yang bertujuan untuk meningkatkan kualitas sumber daya manusia. Salah satu usaha meningkatkan kualitas sumber daya manusia adalah melalui proses pembelajaran di sekolah. Guru merupakan komponen sumber daya pendidikan yang harus dibina dan dikembangkan. Pemerintah telah banyak melakukan upaya perbaikan agar mutu pendidikan meningkat diantaranya perbaikan kurikulum, perbaikan SDM, sarana dan prasarana, memberikan tunjangan dan insentif kepada guru guna menunjang kinerja.

Ada dua jenis tugas pekerjaan mencakup unsur-unsur penting kinerja yaitu: tugas fungsional berkaitan dengan seberapa baik seorang karyawan menyelesaikan pekerjaan, termasuk terutama menyelesaikan aspek-aspek teknis pekerjaan dan berikutnya adalah tugas perilaku berkaitan dengan seberapa baik karyawan menangani kegiatan anatar personal dengan anggota lain organisasi, termasuk mengatasi konflik, mengelola waktu, memberdayakan orang lain, bekerja dalam sebuah kelompok, dan bekerja secara mandiri (Edy Sutrisno, 2010:170)

Kinerja guru berkenaan dengan perilaku dalam menjalankan tugas terdiri dari berbagai aspek diantaranya adalah guru harus dapat menunjukkan perilaku bersungguh-sungguh terhadap pencapaian target dan hasil-hasil setiap pengajaran sesuai dengan yang telah ditetapkan. Sebagaimana tugasnya yang tertuang dalam UU Republik Indonesia
No. 20 Tahun 2003 tentang Sisdiknas pasal 39 ayat (2), menyatakan bahwa pendidik merupakan tenaga profesional yang bertugas merencanakan dan melaksanakan proses pembelajaran, menilai hasil pembelajaran, melakukan pembimbingan dan pelatihan serta melakukan penelitian dan pengabdian kepada masyarakat, terutama bagi pendidik pada perguruan tinggi.

Namun berdasarkan data kinerja guru yang telah penulis pelajari dari SD Negeri 3 Titian Antui ternyata kinerja guru belum maksimal. Hal itu terlihat dari poin-poin yang ada dalam Penilaian Kinerja Guru. Yaitu dalam pelaksanaan pembelajaran guru masih menggunakan cara-cara konvensional. Padahal sudah banyak pelatihan dan seminar yang diadakan dalam rangka meningkatkan kualitas mengajar guru. Selain itu guru belum maksimal dalam menggunakan metode mengajar yang tepat dan sesuai dengan situasi dan kondisi belajar siswa. Guru belum memahami metode penilaian yang baik untuk memantau kemajuan dan hasil belajar peserta didik dari berbagai aspek. Guru juga belum mengembangkan potensi peserta didik sesuai dengan kemampuan siswa. Selain itu guru masih belum menyelesaikan tugas baik dalam pembuatan program pembelajaran dan administrasi tepat waktu. Permasalahan lain adalah ketercapian target tidak sesuai dengan perencanaan. Seperti, belum tuntasnya materi ajar sesuai program dan nilai yang belum mencapai KKM. Pada aspek perencanaan pembelajaran guru belum menyusun RPP sesuai dengan karakteristik peserta didik. Sebagian besar guru memakai kurikulum yang dibuat oleh percetakan dan bersumber dari internet tanpa adanya revisi sesuai dengan kondisi sekolah dan kebutuhan mengajar.

Kinerja guru dipengaruhi oleh beberapa faktor diantaranya seperti 
yang dikemukakan oleh Susanto (1997:17) Kinerja guru dipengaruhi oleh budaya organisasi. Sedangkan menurut Burhanudin (2005:34) Kinerja dipengaruhi supervisi akademik, dan hal ini didukung oleh penelitian yang dilakukan oleh Sachroni , 2013; Jurman, 2014; Mishan, 2014; Endang dan Yelvia Yunita, 2014; Budi Tetuko, 2012, Sa'adah, 2014; Eny Winaryanti dkk, Rosmawati, 2014; 2012; Syukri, 2015. Berdasarkan penjelasan permasalahan yang telah dijelaskan di atas maka penulis tertarik untuk melaksanakan penelitian dengan judul "Pengaruh Budaya Organisasi dan Supervisi Akademik terhadap Kinerja Guru SD di Kecamatan Pinggir Kabupaten Bengkalis"

\section{TUJUAN PENELITIAN}

Penelitian ini bertujuan untuk mengungkapkan fakta-fakta pengaruh budaya organisasi dan supervisi akademik terhadap kinerja guru, tujuan penelitian tersebut adalah sebagai berikut:

1. Untuk menganalisis pengaruh budaya organisasi berpengaruh kinerja guru SD di kecamatan Pinggir kabupaten Bengkalis

2. Untuk menganalisis pengaruh supervisi akademik terhadap kinerja guru SD di kecamatan Pinggir kabupaten Bengkalis.

3. Untuk menganalisis pengaruh budaya organisasi dan supervisi akademik secara bersama-sama terhadap kinerja guru SD di kecamatan Pinggir kabupaten Bengkalis

\section{KAJIAN TEORI}

\section{A. Kinerja Guru}

Menurut Bernardin \& Russel (1993:378) mendefenisikan bahwa kinerja adalah catatan hasil (outcome) yang dihasilkan dari fungsi suatu pekerjaan atau suatu kegiatan tertentu selama satu periode tertentu. Menurutnya kinerja dibatasi oleh waktu hal ini senada dengan pendapat Hasibuan (2007:94) kinerja atau prestasi kerja adalah suatu hasil kerja yang dicapai seseorang dalam melaksanakan tugas yang dibebankan kepadanya yang didasarkan atas kecakapan, pengalaman, dan kesungguhan serta waktu. Dedi Rianto Rahadi (2010:1) mengemukakan performance atau kinerja adalah hasil kerja yang dapat dicapai oleh seseorang atau kelompok orang dalam suatu organisasi, sesuai dengan wewenang dan tanggung jawab masing-masing dalam rangka upaya mencapai tujuan organisasi bersangkutan secara legal, tidak melanggar hukum dan sesuai dengan moral maupun etika.

Kinerja guru merupakan cerminan dari mutu pendidikan, oleh karena itu dalam melaksanakan tanggungjawabnya guru dituntut memiliki kinerja yang baik agar dapat menciptakan generasi bangsa yang berpengetahuan tinggi dengan berlandaskan iman dan taqwa. Sesuai dengan pendapat yang dikemukakan oleh Mc. Clelland (1971:46) bahwa kinerja sebagai cerminan dari keseluruhan cara seseorang dalam menetapkan tujuan prestasinya. Berbeda dengan Mengkunegara (2002:22) yang lebih menekankan pada kualitas menjelaskan bahwa kinerja adalah hasil kerja baik secara kualitas maupun kuantitas yang dicapai seseorang dalam melaksakan tugas sesuai tanggungjawab yang diberikan. Jadi, jelaslah guru yang baik bekerja dengan perencanaan yang matang sehingga tujuan yang direncanakan dapat tercapai.

Pentingnya kinerja guru maka perlu adanya penilaian kinerja agar dapat diukur dan digunakan untuk 
pengambilan keputusan dimasa yang akan datang. Handoko (1994:11) penilaian kinerja merupakan cara pengukuran kontribusi-kontribusi dari individu dalam organisasi. Nilai penting dari penilaian kinerja adalah menyangkut penentuan tingkat kontribusi individu atas kinerja yang diekspresikan dalam penyelesaian tugas-tugas yang menjadi tanggungjawabnya.

Ada banyak faktor yang mempengaruhi kinerja guru. Dalam teori Gibson (1987:73) faktor yang mempengaruhi kinerja adalah faktor dari variabel individu yang terdiri dari kemampuan dan keterampilan, latar belakang dan demografis. Kedua adalah faktor dari variabel psikologi yang terdiri dari persepsi, sikap, kepribadian, motivasi, kepuasan kerja, dan stress kerja. Yang ketiga adalah faktor organisasi yang terdiri dari kepemimpinan, kompensasi, konflik, kekuasaan, struktur organisasi, desain pekerjaan, desain organisasi, dan karir.

Berbeda dengan Agus Dharma (2003:355) menurutnya hampir semua cara pengukuran kinerja mempertimbangkan hal-hal sebagai berikut: (1) Kuantitas, (2) Kualitas, dan (3) Ketepatan waktu. Kinerja guru menurut Tabrani Rusyan (2000:17) adalah melaksanakan proses pembelajaran baik dilakukan di dalam kelas dan diluar disamping mengerjakan kegiatan-kegiatan lainnya seperti mengerjakan administrasi sekolah dan administrasi pembelajaran, melaksanakan bimbingan dan layanan pada para siswa, serta melaksanakan penilaian. Berdasarkan Peraturan Menteri Pendidikan Nasional Republik Indonesia Nomor 16 tahun 2007 tentang Standar Kualifikasi Akademik dan Kompetensi Guru, Adapun macammacam kompetensi guru yang harus dimiliki adalah kompetensi pedagogi, kompetensi kepribadian, kompetensi sosial dan professional. Keempat kompetensi tersebut tersinergi dalam kinerja guru.

Dalam APKG dijelaskan bahwa guru melaksanakan proses pembelajaran dituntut merencanakan dan melaksanakan pembelajaran, mengevaluasi dan menilai hasil pembelajaran, menganalisis hasil pembelajaran, melaksanakan tindak lanjut hasil. Sedangkan dalam melaksanakan proses bimbingan guru harus merencanakan dan melaksanakan pembelajaran, mengevaluasi dan menilai hasil pembelajaran, menganalisis hasil pembelajaran, melaksanakan tindak lanjut hasil pembimbingan.

Berdasarkan teori di atas dapat disintesiskan bahwa kinerja guru adalah perilaku guru dalam menjalankan tugas yang ditransformasikan dalam bentuk tindakan yang berorientasi pada pekerjaan dan hasil kerja yang berkontribusi terhadap pencapaian tujuan pendidikan. Indikator yang digunakan dalam pengukuran kinerja guru adalah (1) Kompetensi Pedagogi, (2) Kompetensi Kepribadian, Kompetensi Sosial, (4) Profesional

\section{B. Budaya Organisasi}

Budaya berdasarkan Kamus Besar Bahasa Indonesia didefinisikan dalam dua pandangan yaitu: pertama hasil kegiatan dan penciptaan batin (akal budi) manusia seperti kepercayaan, kesenian dan adat istiadat; kedua, menggunakan pendekatan ilmu antropologi yaitu keseluruhan pengetahuan manusia sebagai makhluk sosial yang digunakan untuk memahami lingkungan serta pengalamannya dan menjadi pedoman tingkah lakunya. Nilai-nilai yang dikembangkan di sekolah, tentunya tidak dapat dilepaskan 
dari sekolah itu sendiri sebagai organisasi pendidikan, yang memiliki peran dan fungsi untuk berusaha mengembangkan, melestarikan dan mewariskan nilai-nilai budaya kepada para anggotanya.

Menurut Kreitner dan Kinicki (2003:80) nilai-nilai dan keyakinan organisasi merupakan dasar budaya organisasi. Sejalan denan Owens (1991:172) bahwa budaya organisasi adalah studi tentang nilai-nilai dan karakteristik dari sebuah organisasi. Terdapat kesepakatan luas bahwa budaya organisasi merujuk pada sistem pengertian bersama yang dipegang oleh anggota-anggota suatu organisasi yang membedakan organisasi tersebut dengan organisasi lainnya.

Budaya organisasi dalam pendiidkan menurut Salfen Hasri (2005:175) adalah nilai, kepercayaan, kebiasaan dan filosofi organiasi yang dianut dan diyakini oleh karyawan terbentuk melalui pola penarikan karyawan serta pembinaan oleh manajemen lembaga pendidikan. Nilai tersebut terinternalisasi dalam diri karyawan dan mempengaruhi sikap serta perilaku mereka. Menurutnya ada tiga wujud budaya organisasi dilingkungan pendidikan yang dapat dikembangkan yaitu: (1) Budaya kualitas meliputi bangunan fisik, proses belajar mengajar, perpustakaan, teknologi, peningtkatan mutu dosen, layanan dan partisipasi karyawan serta dosen, praktik kuliah manajemen dan akuntansi pelatihan Bahasa Inggris, bahasa Mandarin dan Bahasa Jepang, (2) budaya kekeluargaan dan, (3) budaya kebersamaan dan suka menolong.

Pengaruh kekuatan budaya terhadap pencapaian organisasi juga dibahas oleh Robbins (2002:250). Menurut Robbin suatu budaya yang kuat memperlihatkan kesepakatan yang tinggi di kalangan anggota mengenai apa yang dipertahankan organisasi itu. Hal itu menunjukkan jika suatu organsasi memiiki budaya yang kuat maka mereka akan terus bertahan dan tidak akan ada anggota yang memiliki pemikiran untuk meninggalkan organisasi sebab mereka searah dengan arah tujuan organisasi. Jadi adanya budaya kuat karena banyaknya anggota yang menerima nilai-nilai inti dan semakin menigkatkan komitmennya.

Menurut Wibowo (2010:35) akar dari suatu budaya organisasi adalah serangkaian karakteristik inti secara kolektif dihargai oleh semua anggota organisasi. Karakteristik budaya organisasi menunjukkan ciri-ciri, sifatsifat unsur-unsur, atau elemen-elemen yang terdapat dalam suatu budaya organisasi. Fred Luthans (2000:123) dalam Perilaku Organisasi menyebutkan sejumlah karakteristik budaya Organisasi antara lain: (1) Aturan perilaku yang diamati, (2) Norma, (3) Nilai dominan, (4) Filosofi, (5) Aturan, (6) Iklim organisasi.

Budaya organisasi memiliki empat karakteristik. Pertama,budaya organisasi bersifat khusus (distinctive) karena masing-masing organisasi memiliki sejarah, pola komunikasi, sistem dan prosedur, pernyataan visi dan misi serta mitos-mitos. Kedua, budaya organisasi itu pada hakikatnya stabil danbiasanya lambat berubahnya. Budaya organsiasi akan berubah bila ada ancaman krisis atau terjadi merger dengan organsasi yang lain. Ketiga, budaya organsasi biasanya memiliki sejarah implisit dan tidak eksplisit. Keempat, budaya organsasi tampak sebagai perwakilan simbol yang melandasi keyakinan dan nilai-nilai organisasi tersebut (Nurkolis, 2003:206)

Fungsi budaya organisasi menurut Rizal dan Mulyadi (2012:373) adalah sebagai berikut: (1) Budaya mempunyai 
suatu peran menetapkan tapal batas, artinya budaya menciptakan perbedaan yang jelas antara satu organisasi yang satu dengan organisasi yang lain, (2) Budaya memeberikan identitas bagi anggota orgnisasi, (3) Budaya mempermudah timbulnya komitmen yang lebih luas dan pada kepentingan individu, (4) Budaya itu meningkatkan kemantapan sistem sosial dan, (5) Budaya sebagai mekanisme pembuat makna dan kendali yang memandu serta membentuk sikap dan perilaku karyawan.

Budaya memiliki peran dalam setiap organisasi. Andreas Lako (2006:112) menurutnya peran budaya organisasi adalah sebagai alat untuk menentukan arah organisasi, mengarahkan apa yang boleh dilakukan dan yang tidak boleh dilakukan, bagaimana mengalokasikan sumber daya dan mengelola sumber daya organisasional, dan juga sebagai alat untuk menghadapi masalah dan peluang dari lingkungan internal dan eksternal.

Dari uraian tentang budaya organisasi di atas dapat disintesiskan bahwa budaya organisasi adalah nilai, norma, etika, dan kebiasaan diyakini bersama yang dijalankan oleh anggota organisasi, sifatnya mengikat perilaku anggotanya, digunakan dalam penyelesaian masalah demi meningkatkan keefektifan organsiasi, dan dijadikan sebagai pedoman untuk pencapaian tujuan organsasi. Dengan karakteristik sebagai berikut: (1) Pemahaman anggota organisasi terhadap visi misi organisasi, (2) Penerimaan anggota organisasi terhadap peraturan organisasi, (3) Tradisi yang dianut.

\section{Supervisi Akademik (X2)}

Pengertian supervisi menurut Piet Sahertian (2000:19) mengatakan bahwa supervisi tidak lain adalah usaha memberi layanan kepada guru-guru baik secara individual maupun secara kelompok dalam usaha memperbaiki pengajaran. Kata kunci dari pemberian supervisi pada akhirnya ialah memberikan layanan dan bantuan.

Sedangkan supervisi akademik menurut Mulyasa (2012:249) adalah bantuan professional kepada guru, melalui siklus perencanaan yang sistematis, pengamatan yang cermat, dan umpan balik yang objektif dan segera. Tujuan supervisi akademik adalah untuk meningkatkan kualitas pembelajaran melalui pembelajaran yang baik. Senada dengan pendapat Syaiful Sagala (2000:246) Fungsi dan spesifikasi supervisi pengajaran memberikan pelayanan supervisi pengajaran untuk menumbuhkan proses belajar mengajar yang lebih baik dan dapat menjaga keseimbangan pelaksanaan tugas staf mengajar.

Adapun tahapan yang dilakukan dalam pelaksaaan supervisi menurut Daryanto (2001:187) adalah : (1) Perencanaan dilakukan bersama-sama secara demokratis oleh kepala sekolah dan guru kelas yang akan dikunjungi, berdasarkan kesulitan yang telah dialami, apa yang akan diobservasi, kapan waktu yang sebaik-baknya, (2) Pelaksanaan: observasi dilakukan seinformal mungkin, (3) Penganalisaan: dilakukan setelah observasi. Dilakukan bersama-sama oleh kepala sekolah dan guru untuk membicarakan hasil observasi dan mencari segi kelebihan dan kekurangan dan, (4) Kesimpulan dan penilaian: kesimpulan sebagai penilaian terakhir dilakukan juga secara kooperatif, dengan disadari dan disetujui sepenuhnya oleh yang bersangkutan.

Tujuan supervisi menurut Mukhtar dan Iskandar (2009:52) supervisi bertujuan mengembangkan 
situasi kegiatan pembelajaran yang lebih baik ditujukan pada pencapaian tujuan pendidikan di sekolah, membimbing pengalaman mengajar guru, menggunakan alat pembelajaran yang modern, dan membantu guru dalam menilai kemajuan peserta didik

Dalam Eny Winarti (2012:316) Adapun indikator supervisi akademik oleh kepala sekolah adalah: (1) Perencanaan program supervisi akademik, (2) Pelaksanaan program supervisi akademik, dan (3) Tindak lanjut program supervisi akademik.

Berdasarkan Peraturan menteri Pendidikan Nasional Republik Indonesia Nomor 13 tahun 2007 tentang Standar Kepala sekolah/Madrasah kepala sekolah harus memiliki kompetensi supervisi meliputi perencanaan program supervisi akademik dalam meningkatkan kinerja guru meliputi perumusan program supervisi, pengaturan jadwal, dan penentuan teknik dan pendekatan supervisi akademik. Selanjutnya pelaksaaan supervisi akademik dalam menilai perencanaan mengajar, pelaksanaan dan evaluasi mengajar guru. Berikutnya adalah evaluasi dan tindak lanjut supervisi akademik terhadap guru.

Berdasarkan teori di atas dapat disintesiskan bahwa budaya organisasi adalah nilai, norma, etika, dan kebiasaan diyakini bersama yang dijalankan oleh anggota organisasi, sifatnya mengikat perilaku anggotanya, digunakan dalam penyelesaian masalah demi meningkatkan keefektifan organsiasi, dan dijadikan sebagai pedoman untuk pencapaian tujuan organisasi. Dengan indikator sebagai berikut: (1) Pemahaman anggota organisasi terhadap visi misi organisasi, (2) Penerimaan anggota organisasi terhadap peraturan organisasi, Tradisi yang dianut.

\section{METODOLOGI PENELITIAN}

\begin{tabular}{lrr}
\multicolumn{2}{c}{ Penelitian ini menggunakan } \\
metode desktiptif & menggunakan \\
pendekatan kuantitatif. & Adapun \\
penelitian ini bertujuan & mengetahui \\
pengaruh/menggambarkan & antara \\
variable independen & (variable
\end{tabular}
mempengaruhi) yaitu $(\mathrm{X})$ dan variable dependen (yang dipengaruhi) yaitu (Y). Yang menjadi populasi dalam penelitian ini adalah semua guru PNS yang mengajar di SD Negeri Kecamatan Pinggir Kab. Bengkalis berjumlah 215 orang. Penarikan sampel menggunakan Rumus Slovin dengan nilai kritis (batas ketelitian) $5 \%$ maka ukuran sampel penelitian diperoleh 140 guru. Pemilihan sampel dilakukan secara Proportional Random Sampling. 


\section{HASIL PENELITIAN DAN PEMBAHASAN}

\section{A. Pembahasan Hasil Penelitian \\ 1.Pengaruh Budaya Organisasi Terhadap Kinerja Guru}

\begin{tabular}{|c|c|c|c|c|c|c|}
\hline \multicolumn{7}{|c|}{ Coefficients $^{\mathbf{a}}$} \\
\hline & \multirow[b]{2}{*}{ Model } & \multicolumn{2}{|c|}{$\begin{array}{c}\text { Unstandardized } \\
\text { Coefficients }\end{array}$} & \multirow{2}{*}{$\begin{array}{c}\begin{array}{c}\text { Standardized } \\
\text { Coefficients }\end{array} \\
\text { Beta }\end{array}$} & \multirow[b]{2}{*}{$\mathrm{t}$} & \multirow[b]{2}{*}{ Sig } \\
\hline & & B & Std. Error & & & \\
\hline \multirow[t]{3}{*}{1} & (Constant) & 73.826 & 8.957 & & 8.242 & .000 \\
\hline & Budaya Organisasi & .231 & .059 & .312 & 3.887 & .000 \\
\hline & Supervisi Akademik & .107 & .061 & .141 & 1.761 & .081 \\
\hline
\end{tabular}

a. Dependent Variable: Kinerja Guru

Dari tabel di atas dapat dilihat nilai $\mathrm{t}$ hitung $=3,887$ diketahui $\mathrm{n}=140$ maka $\mathrm{df}=$ $\mathrm{n}-\mathrm{k}, 140-2=138$. Dibandingkan dengan nilai $t_{\text {tabel }}$ pada df 138 dengan taraf signifikan $5 \%$ maka didapat nilai $t_{\text {tabel }}=$ 1,655. Kemudian dibandingkan antara $t_{\text {tabel }}$ dan thitung 3,887>1.655 maka Ho ditolak dan $\mathrm{Ha}$ diterima. Artinya secara signifikan budya organisasi berpengaruh terhadap kinerja guru SD Negeri Kec. Pinggir Kabupaten Bengkalis. Adapun persamaannya sebagai berikut:

$\hat{\mathrm{Y}}=\mathrm{a}+\mathrm{b}_{1} \mathrm{X}_{1}$

$\hat{Y}=73.826+0,231 X_{1}$

Artinya terdapat peningkatan satu satuan skor budaya organisasi dapat meningkatkan skor kinerja guru sebesar 0,231 pada konstanta 73,826. Dari hasil perhitungan standardize koefisien beta didapat pengaruh budaya oganisasi secara parsial terhadap kinerja guru sebesar $0,3122=0.097$. Artinya dalam penelitian ini budaya organisasi mempengaruhi kinerja guru sebesar 9,7 $\%$.

Budaya organisasi berpengaruh signifikan terhadap kinerja guru. Hasil penelitian ini sesuai dengan yang dikemukakan oleh Susanto (1997:17), bahwa organisasi yang kondusif akan meningkatkan gairah belajar dan prestasi kerja karyawan, hal ini juga pada organisasi sekolah, jika budaya organisasi sekolah kondusif maka kinerja semakin meningkat.

Berkenaan dengan penelitian terdahulu juga sudah ada yang mengaitkan antara budaya organisasi dengan kinerja guru, yakni penelitian Jurman (2014) dalam penelitiannya di SMA budaya berpengaruh positif dan signifikan terhadap kinerja guru. Mishan (2014) dalam penelitiannya terhadap guru SMA bahwa budaya organisasi memerikan pengaruh yang signifikan terhadap kinerja guru

\section{Pengaruh supervisi akademik terhadap kinerja guru}

Dari tabel di atas dapat dilihat nilai t hitung $=1,761$ diketahui $\mathrm{n}=140$ maka $\mathrm{df}=\mathrm{n}-\mathrm{k}, \quad 140-2=138$. Dibandingkan dengan nilai tabel pada df 138 dengan taraf signifikan 5\% maka didapat nilai $t_{\text {tabel }}=1,655$. Kemudian dibandingkan antara $t_{\text {tabel }}$ dan $t_{\text {hitung }}$ 1,761>1.655 maka Ho ditolak dan $\mathrm{Ha}$ diterima. Artinya secara signifikan budya organisasi berpengaruh terhadap kinerja guru SD Negeri Kec. Pinggir 
Kabupaten Bengkalis. Adapun

Budaya organisasi berpengaruh persamaan regresinya adalah: terhadap kinerja guru. Hasil penelitian $\hat{\mathrm{Y}}=\mathrm{a}+\mathrm{b} 2 \mathrm{X} 2$ ini sesuai dengan yang dikemukakan $\hat{Y}=73.826+0.107 \mathrm{X} 2$ oleh Burhanudin (2005:34) bahwa Artinya terdapat peningkatan satu faktor-faktor yang mempengaruhi

\begin{tabular}{|l|c|c|c|c|}
\hline \multicolumn{1}{|c|}{ Variabel } & Standar & Sig & Kesimpulan & Pengaruh \\
& Koefisien & S value) & Statistik & \\
& Beta & & & \\
\hline Budaya Organisasi & 0,312 & 0,000 & Signifikan & $9,7 \%$ \\
\hline Supervisi Akademik & 0,141 & 0,081 & No Signifikan & $2 \%$ \\
\hline R2: 0,125 & & & \\
p-Value :0,000 & & & \\
\end{tabular}

satuan skor supervisi akadmik dapat meningkatkan skor kinerja guru sebesar 0,107 pada konstanta 73,826. Dari hasil perhitungan standardize koefisien beta didapat pengaruh supervisi akademik secara parsial terhadap kinerja guru sebesar $0,141^{2}=0.019$. Artinya dalam penelitian ini budaya organisasi mempengaruhi kinerja guru sebesar 1,9 $\%$.

Berkenaan dengan penelitian terdahulu juga sudah ada yang mengaitkan antara budaya organisasi dengan kinerja guru, yakni penelitian Sa'adah (2014) pada Sekolah Dasar bahwa peningkatan kinerja guru dapat ditingkatkan melalui supervisi akademik. Hasilnya supervisi akademik dapat meningkatkan kinerja guru pada aspek penyusunan RPP, pelaksanaan pembelajaran, penyusunan program perbaikan serta dapat meningkatkan kompetensi guru dalam mengadakan pelaksanaan pengayaan kepada siswa. Dalam penelitian Eny Winarty (2012) pada pembelajaran IPA di SMP kepala sekolah yang merencanakan program kinerja guru diantaranya tingkat pendidikan guru, supervisi pengajaran, program penataran, iklim yang kondusif, sarana dan prasarana, kondisi fisik dan mental guru, gaya kepemimpinan kepala sekolah, jaminan kesejahteraan, kemampuan manajerial kepala sekolah, pelatihan, pemberian insentif.

supervisi akademik, melaksanakannya serta menindaklanjuti hasil supervisi dalam rangka peningkatan profesionalisme guru dan kualitas pengajaran perlu dilakukan. Rosmawati dalam penelitiannya dalam meningkatkan kemampuan mengajar terhadap guru kimia melalui supervisi akademik. Ia melakukan melalui penelitian tindakan sekolah. Hasilnya terjadi peningkatan kemampuan mengajar guru setelah dilakukan supervisi. Pada penelitian syukri juga mendapati bahwa pelaksanaan supervisi akademik oleh kepala sekolah dapat meningkatkan kinerja guru. 


\section{Pengaruh budaya organisasi dan supervisi akademik terhadap kinerja guru}

\begin{tabular}{|c|c|c|c|c|}
\hline \multicolumn{5}{|c|}{ Model Summary } \\
\hline Model & $\mathrm{R}$ & R Square & $\begin{array}{c}\text { Adjusted R } \\
\text { Square }\end{array}$ & $\begin{array}{c}\text { Std. Error of the } \\
\text { Estimate }\end{array}$ \\
\hline 1 & $.353^{\mathrm{a}}$ & 0.125 & 0.112 & 6.356 \\
\hline
\end{tabular}

Berdasarkan model summary di atas dapat dijelaskan bahwa kinerja dioengaruhi oleh budaya organisasi dan supervisi akademik sebesar $12.5 \%$. Budaya organisasi memberikan pengaruh sebesar $9.7 \%$ dan supervisi akademik memberikan pengaruh sebesar $2 \%$.

Berdasarkan hasil dari $\mathrm{F}_{\text {hitung }}=$ 9.780 $>\mathrm{F}_{\text {tabe }}=3.06$ dengan taraf signifikansi 0,05, maka Ho ditolak yang menjelaskan bahwa terdapat pengaruh signifikan budaya organisasi dan supervisi akademik secara simultan terhadap Kinerja guru.Berdasarkan tabel di atas, dapat dibuat persamaan regresi budaya organisasi dan supervisi akademik terhadap kinerja guru adalah:

$\hat{\mathrm{Y}}=\mathrm{a}+\mathrm{b} 1 \mathrm{x} 1+\mathrm{b} 2 \mathrm{X} 2$

$\hat{\mathrm{Y}}=73.826+0,231 \mathrm{X} 1+0.107 \mathrm{X} 2$

Artinya terdapat peningkatan satu satuan skor budaya organisasi dan supervisi akadmik dapat meningkatkan skor kinerja guru masing-masing 0,231 dan 0,107 pada konstanta 73,826

Berdasarkan hasil SPSS di atas budaya organisasi dan supervisi akademik berpengaruh signifikan terhadap kinerja guru sebesar 12,5\%. Sisanya $(1-0,125=0.875) \quad 87,5 \%$ dipengaruhi oleh faktor lain seperti motivasi sesuai dengan teori yang dikemukakan oleh Moekijat (1999:25) bahwa suatu tingkatan motivasi yang tinggi dapat mengakibatkan moral yang tinggi mempunyai hubungan yang positif terhadap hasil kerja yang tinggi.
Hasil penelitian ini juga didukung oleh penelitian Endang (2014) dalam penelitiannya terhadap guru di SMA bahwa dari penelitiannya diketahui budaya organisasi mempengaruhi kinerja guru. Sedangkan penelitian Rosmawati (2014) terhadap guru SMA diketahui bahwa supervisi akademik berpengaruh signifikan terhadap kinerja guru.

\section{SIMPULAN DAN SARAN}

\section{Simpulan}

Berdasarkan analisis data dan pengujian hipotesis penelitian, maka dapat diambil bebrapa kesimpulan sebagai berikut:

Pertama, secara simultan terdapat pengaruh budaya organisasi dan supervisi akademik terhadap kinerja guru SD Negeri Kecamatan Pinggir Kabupaten Bengkalis. Hal ini menggambarkan bahwa apabila budaya organisasi di sekolah dan supervisi akademik ditingkatkan maka akan terjadi peningkatan kinerja guru.

Kedua, secara parsial terdapat pengaruh budaya organisasi terhadap kinerja guru SD Negeri Kecamatan Pinggir Kabupaten Bengkalis. Dalam penelitian ini budaya organisasi mempengaruhi kinerja guru secara signifikan.

Ketiga, secara parsial terdapat pengaruh supervisi akademik terhadap kinerja SD Negeri Kecamatan Pinggir 
Kabupaten Bengkalis tetapi pengaruhnya tidak signifikan.

\section{Saran}

Berdasarkan hasil penelitian ini maka disarankan sebagai berikut: Pertama, hasil penelitian menunjukkan bahwa pengaruh budaya organisasi terhadap kinerja guru sangat kecil. Artinya budaya atau nilai-nilai yang ada dilingkungan organisasi sekolah tidak berjalan sesuai dengan yang diharapkan anggota organisasi. Artinya kepala sekolah harus lebih memperhatikan dan membiasakan kepada anggota organisasi dalam penerapan budaya atau kebiasaan-kebiasaan yang mampu menciptakan lingkungan kerja yang kondusif sehingga dapat meningkatkan kinerja guru.

Kedua, Hasil penelitian menyimpulkan bahwa supervisi akademik terhadap kinerja guru juga memberikan pengaruh yang kecil karena supervisi akademik tidak berjalan sesuai dengan yang telah diprogramkan oleh kepala sekolah sehingga perlunya program kerja yang jelas dan pelaksaan supervisi akademik secara konsisten agar kualitas mengajar guru.

\section{G. DAFTAR PUSTAKA}

Bernardin, H. John and Joyce E.A. Russel.. (1993). Human Resource Management An Experiental Approach. Mc. Graw hill, Inc. New York.

D.C. Winter Mc. Clelland. (1971). Motivation Economic Achievment. The Free Pers: New York
Dharma, Agus. (2003). Manajemen Supervisi. Raja Grafindo Persada: Jakarta

Daryanto. (2001). Administrasi Pendidikan. Rineka. Cipta: Jakarta

Endang, Tirtana Putra, dan Yelvia Yunita. (2014). Pengaruh Kepemimpinan Kepala Sekolah dan Budaya Organisasi Terhadap Kinerja Guru SMA Negeri 1 Simpang Empat . ISSN 2337-3997 Vol 2 No 3

Eni Winarti dan Mufnaety. (2012). Kompetensi Kepala Sekolah Sebagai Supervisor Pada Pembelajaran IPA SMP di Kota Semarang.ISBN : 978602-18809-0-6

Gibson et all. (1987). Perilaku, Struktur, Proses. Jakarta: Erlangga

Handoko Hani. (1994). Manajemen Personalia dan Sumber Daya Manusia. Yogyakarta: BPFE

Hasri, Salfen. (2005). Manajemen Pendidikan: Pendekatan Nilai dan Budaya Organisasi. Yapma: Makasar

Jurman, (2014). Budaya Organisasi Dalam Mengingkatkan Kinerja Guru Pada SMA Negeri 1 Simeulue Timur. ISSN 1411612x Vol.XIV No.2

Kreitner, Robert dan Angelo Kinicki. (2003). Perilaku Organisasi. Salemba Empat: Jakarta 
Kreitner, Robert. (2000). Management. Houghton Miffin Company: USA

Luthans, Fred. (2008). Perilaku Organisasi. Edisi 10. Andi: Yogyakarta

Mishan. (2014). Pengaruh Motivasi Kerja Guru dan Budaya Organisasi Terhadap Kinerja Guru SMA Negeri Di Kota Sibolga ISNN 2356-3893 Vol 1 No 2

Nurkolis. (2003). Manajemen Berbasis Sekolah. Jakarta: Grasindo

Owens, Robet G. (1991). Organizational Behavior in Schools. USA: Prentice Hall

Robbins, Stephen P. (2002). Perilaku Organisasi. Edisi ke 8. Pearson Education Asia: Jakarta

Rivai, Veithzal dan Deddy,M. (2009). Kepemimpinan dan Perilaku Organisasi. Rajawali Pers: Jakarta.

Rosmawati. (2014). Upaya Meningkatkan Kemampuan Mengajar Guru Kimia Melalui Supervisi Akademik Model Ilmiah di SMA Negeri Kota Takengon. ISSN: 1979-6684

Sa'adah. (2014). Peningkatan Kompetensi Guru Melakukan penilaian Proses Pembelajaran Melalui Supervisi Akademik. ISSN 2355-9683

Sagala, Syaiful. (2000). Administrasi Pendidikan Kontemporer. Bandung: Alfabeta
Sahertian, Piet. (2000). Supervisi Pendidikan. Rineka Cipta: Jakarta

Sutrisno Edy, (2010). Budaya Organisasi. Kencana Prenada Media group: Jakarta

Sukri, dkk. (2015). Pelaksanaan Supervisi Akademik Oleh Kepala Sekolah Untuk Meningkatkan Kinerja Guru Sekolah Dasar Pada Gugus I UPTD Dewantara Acah Utara. ISSN 2302-0156

Susanto. (2005). Perilaku Organisasi. Bogor: PT. Ghalia Indonesia

Susanto, dkk. (2006). Strategi Organisasi. Amara Books: Yogyakarta

Syachroni. (2013). Analisis Faktor Yang Mempengaruhi Kinerja Guru SMA N 4 Jambi. Jurnal Dinamika Manajemen. Vol. 1 No. 2. ISSN: $2338-123 \mathrm{X}$

Tabrani, Rusyan dkk. (2000). Upaya Meningkatkan Budaya Kinerja Guru. Cianjur: Dinamika Karya Cipta

Tetuko, Budi. (2012). Pengaruh Motivasi Kerja, Budaya Organisasi, Kepemimpinan Kepala Sekolah Terhadap Kepuasan Kerja dan Kinerja Guru SMA Swasta di Kabupaten Grobokan. ISSN 2252-7001

Undang-Undang Republik Indonesia No 22, Tahun 1999, tentang pemerintah Daerah 